\title{
MICROBIAL TRANSGLUTAMINASE: SOURCE, PRODUCTION AND ITS ROLE TO IMPROVE SURIMI PROPERTIES
}

\section{Microbial Transglutaminase: Sumber, Produksi dan Peranannya untuk Memperbaiki Sifat Surimi}

\author{
Dewi Seswita Zilda ${ }^{1}$ \\ ${ }^{1}$ Research and Development Center for Marine and Fisheries Product Processing and Biotechnology, \\ JI. K.S. Tubun Petamburan VI, Jakarta Pusat 10260, Indonesia, *Correspondence Author: seswitazilda@yahoo.com \\ Article history: \\ Received: 10 December 2013; Revised: 21 April 2014; Accepted: 22 April 2014
}

\begin{abstract}
Transglutaminases (EC 2.3.2.13) have attracted a wide interest from both scientific and applied points of view due to their capacity to cross-link protein substrates. Obtaining transglutaminases derived from animals are extremely high cost process, which has hampered its wider application until the discovery of transglutaminase produced by microorganisms. In the early 1990, since microbial transglutaminase have been found, many transglutaminase-producing microbial strains have been isolated and the enzyme production processes have been optimized. This resulted in the increased uses of transglutaminases in the food industries. In the fisheries industry, MTGase has successfully been used to improve the mechanical properties of surimi from various fishes.
\end{abstract}

Keywords: Microbial transglutaminase (MTGase), surimi

\section{ABSTRAK}

Transglutaminases (EC 2.3.2.13) merupakan enzim yang diminati secara luas baik dari segi ilmiah maupun untuk aplikasi karena kemampuannya dalam membentuk ikatan silang substrat protein. Transglutaminase yang berasal dari hewan mempunyai harga sangat tinggi yang menjadi kendala untuk aplikasi lebih luas. Sejak awal 1990-an setelah ditemukannya Streptomyces mobaraensis, sudah banyak dilaporkan mikroorganisme yang mampu menghasilkan enzim ini dan proses optimasi produksinya juga sudah banyak dilakukan. Dampaknya adalah meningkatnya aplikasi enzim ini pada industry makanan. Dalam industri perikanan MTGase telah digunakan untuk meningkatkan sifat mekanik surimi yang dihasilkan dari berbagai jenis ikan.

Kata Kunci: Microbial transglutaminase (MTGase), surimi

\section{Introduction}

Transglutaminases (TGase: protein-glutaminase $\gamma$ glutamyltransferase, EC 2.3.2.13) comprise a class of enzymes catalyzing the substitution of the amide ammonia with another amine at the $\gamma$-position in glutamine residues, normally an 1 -amino group from a suited lysine residue (Dadabay and Pike, 1989). The establishment of 1-( $\gamma$-glutamyl) lysine isopeptide bonds produce both intra- and inter molecular crosslinking of proteins, which lead to polymerization. (Figure 1).

Until the end of the 1980s, guinea pig liver was the only source for commercial transglutaminase. The price for the enzyme was extremely high due to the rare source and complicated downstream procedure, which hampered its wide range of applications in food processing (Zhu \& Tramper, 2008). The production of transglutaminase from microorganisms have received increasing interest after Streptomyces mobaraensis was reported to produce transglutaminase (Ando et al., 1989). Since then, screening of new strains capable of producing tranglutaminase have been carried out (Neilson, 1995; Kobayashi et al., 1998; Liu et al., 2007) and effors to enhance enzyme yield and production has been conducted through various methods (Sommer et al., 2011; Kittikun et al., 2011; Guera-Rodriguez \& Vázquez, 2013a, 2013b; GueraRodriguez et al., 2012a, 2012b). ,

Recently, Microbial Transglutamine (MTGase) has been used for food processing and has been shown to improve the flavour, appearance andtexture of various protein-based foods. Surimi is the minced fish meat that has been washed to remove fat, water-soluble 


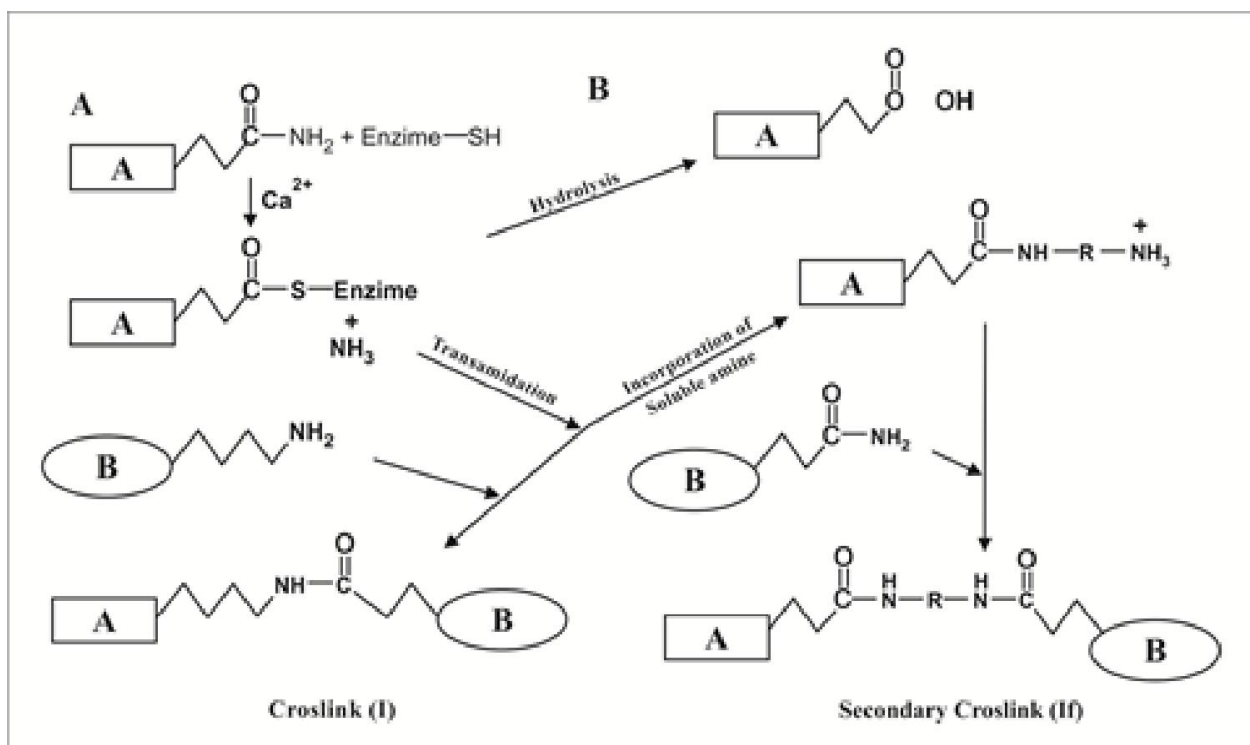

Figure 1. Reactions catalysed by TGases. (A) TGase forms a covalent intermediumte between the active-site thiol residue and a glutamine residue releasing of ammonia. (B) thioester undergoes either hydrolysis (an unfavourable reaction), releasing glutamic acid in the substrate protein, or (C) an acyl transfer to a primary amine resulting 1) a simple amine-isopeptidyl adduct, 2)Polymerization form cross-link II 3 ) in the second instance a direct glutamyl-lysine protein cross-link is produced (cross-link I). (Griffin et al., 2002).

proteins and undesirable muscle components such as blood and pigments. This process result in the concentrated myofibrillar proteins, which directly contribute to gelation (Iwata et al., 2001). Surimi has been used as the primary ingredient in a variety of processed foods such as kamaboko, chikuwa, fish sausages, fish balls, etc. The prime factor to determine the quality of surimi is the mechanical properties. Many approaches for improving the texture of surimi-based products have been therefore proposed and implemented i.e addition of transglutaminase. We will describe the sources of MTGase , the optimization of its production, and its application to improve the quality of surimi.

\section{Source of Microbial Transglutaminase}

TGase identified in all of mammalian members require calcium as a cofactor (Kumazawa et al., 1997). Although MTGase are a variant of the transglutaminase family, but their calcium independent catalysis are distinct by virtue of the isopeptide bond formation (Aluko \& Yada, 1999; Pastemack et al., 1998). MTGaseis $38-\mathrm{kDa}$ enzyme which is expressed as a zymogen and activated through $\mathrm{N}$-terminal cleavage (Pastemack et al., 1998; Kanaji et al., 1993; Zotzel et al., 2003). Very little sequence similarity was shown by MTGase isolated from Streptomyces mobaraensisto any mammalian TGase, whose molecular weights are greater than $70 \mathrm{kDa}$ (Piredda et al., 2003). Although sharing a similar function as its mammalian counterparts but MTGase exhibits more robust catalytic properties, including high stability throughout a broad range of $\mathrm{pH}$ and temperatures in comparison with other TGase (Shi et al., 2011). The crystal structure of MTGase from Streptomyces mobaraensis is presented in Figure 2.

After the discovery of S.mobaraensis, further screening effort has led to the isolation of other MTGase-producing Streptomyces, such as Streptomyces sp. (Neilson, 1995), Streptoverticillium cinnamoneum (Duran et al., 1998), Streptoverticillium ladakanum (Ashie \& Lanier, 2000), Streptomyces fradiae (Liu et al., 2007), Streptomyces. Hygroscopicus (Cui et al., 2007), Strepmyces lividans and Streptomyces platensis (Lin et al., 2006). Pseudomonas species was also reported to produce transglutaminase. Some notable examples include Pseudomonas putida, Pseudomonas amyloderamosa and Pseudomonas palleroni, (Bech et al., 2001). Other MTGase microbial producers include Bacillus substilis (Kobayashi et al., 1998), Zygomonas mobilis and Hafnea alvei (Bech et al., 2002). Kittikun et al. (2012) reported Enterobactersp. C2361 and Providencia sp. C1112 as active MTGase-producing strains isolated from waste water and flock-floating. 

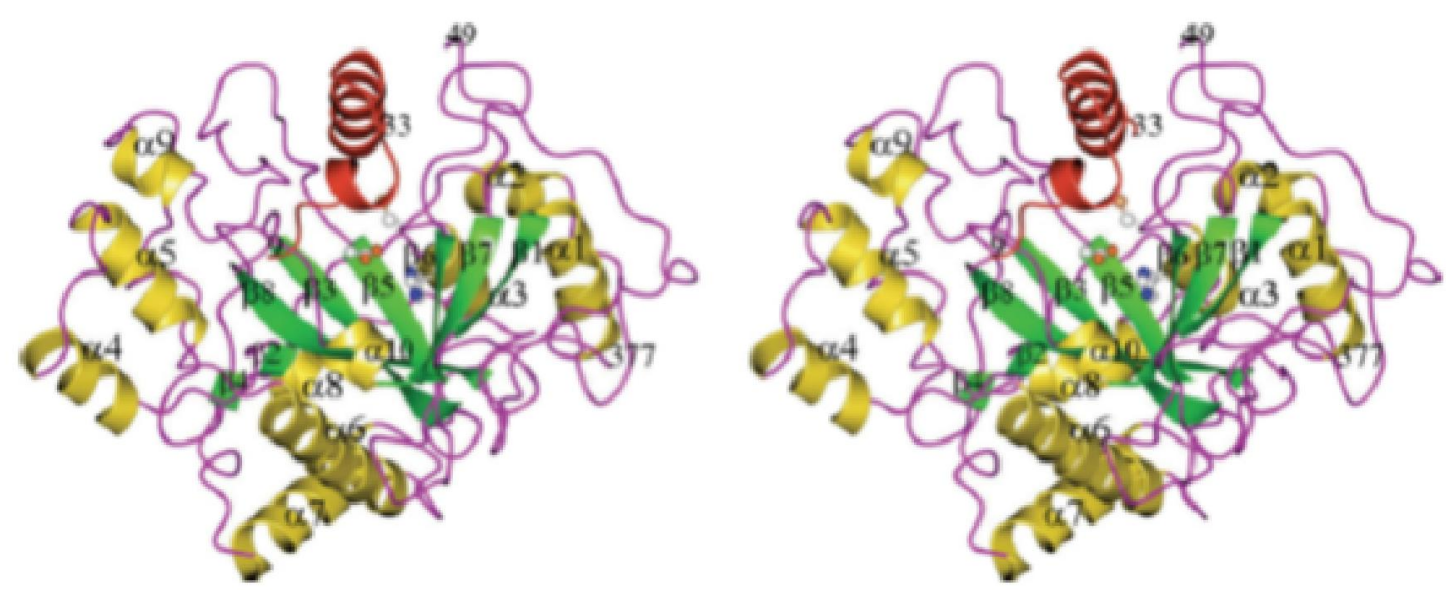

Gambar 2. Stereo view of the overall structure of the MTGase zymogen generated with program CCP4MG. The visible portion of prosequence (residues 9-33) of the zymogen has been colored red. Reprinted from: Crystal Structure and Inhibition Studies of Transglutaminase from Streptomyces mobaraense. Yang, M. T., Chang, C. H., Wang, J. M., Wu, T. K., Wang, Y. K., Chang, C. Y., \& Li, T. T. 2011. Journal of Biological Chemistry. 286, 7301-7307.

Using molecular approach, Patantis et al. (2008) screened 98 bacterial isolates from culture collection hosted at Research and Development Center for Marine and Fisheries Product Processing and Biotechnology (RDCMFPPB) and Institute of Indonesian Science (LIPI). A pair of primers used was PTGase 4 (5'-TACGGCTGCGTCGGTGTCAC-3') dan PTGase 5 (5'-GACGGTCGTGATTGCCTCC-3') with Streptoverticillium ladakanum as the positive control. The result showed that there are 3 isolates exhibiting PCR-amplification of 400-bp fragments, which are considered as the fragments of transglutamniase.

Over-production of MTGase have been examined using various host strains. For example, MTGase production was heterologously expressed as intracellular inclusion body or pro-MTGase using Escherichia coli, which required additional processing by a subtilisin-like protease to produce the mature form of recombinant MTGase (Yokoyama et al., 2000; Yang et al., 2009). Corynebacterium glutamicum was reported as the host for efficient MTGase production. However, it was also secreted as pro-MTGase (Kikuchi et al., 2003). The Active form of MTGase from Streptomyces albogriseolus was successfully produced by constructing a strain of $C$. glutamicum that co-expressed pro-MTGase and SAM-P45 (Date et al., 2003).

Ogino et al. (2004) constructed a heterologous over-production system for the secretory phospholipase D using S. lividans as the expression host. They assumed that this vector would be suitable for the production of active-form MTGase because the vector used in this system contained putative promoter and terminator regions, and the signal peptide sequence (pld signal) derived from the $S$. cinnamoneus phospholipase D gene. MTGase from S. mobaraensis was reported to have 416 residues, including a predicted pre-region of 32 residues, pro-region of 54 residues, and mature region of 330 residues (Washizu et al., 1994). Pro-domain of transglutaminase from $S$. cinnamoneus, which shows $62.2 \%$ identity to that of the transglutaminase from S. mobaraensis, was fused to the N-terminus of MTGase, resulting in the successful production of active-form MTGase from $C$. glutamicum (Date et al., 2003).

Noda et al. (2013) successfully produced MTGase using a genetically modified strain of $S$. lividans. The pld-signal and prepro-domain of $S$. cinnamoneus transglutaminase contributed to the effective secretion of MTGase. This is the first report demonstrating the efficient production of mature active-form MTGase using S. lividans.

\section{Optimization of Production}

MTGase,in particular produced by Streptomyces mobaraensis, has been widely used as catalyst in various industry due to its rather broad substrate specificity for acyl acceptors and its independence of $\mathrm{Ca} 2+$, which are distinct from animal transglutaminases (Tanaka, 2004). The studies on transglutamaninase production from Streptoverticillium and Streptomyces had been carried out to obtain economical optimal methods (Motoki \& Seguro, 1998; Ando et al., 1989). Production of MTGase industrially was conducted by extracting the 
enzyme from culture medium. The enzyme free culture is separated from remain medium component and transferred into a product in powder form.

Since it was published by Ando et al. (1989), the medium composition for MTGase productions from Streptomyces has been almost the same which contains yeast extract, peptone, sodium phosphate, potassium phosphate, magnesium sulphate and a carbon source (Portilla- Rivera et al., 2009; Bahrim et al., 2010; Aidaroos et al., 2011; Zheng et al., 2001).The common carbon sources used are glucose (Bahrim et al., 2010), starch (Zheng et al., 2001), solubilized starch (Kittikun et al., 2012; Bourneow et al., 2012) anddextrins (Guerra-Rodríguez \& Vazquez, 2013b). However, to be economically acceptable for industrialscale, the source of culture medium should not only abundant but also cheap. The formulation of culture medium was crucially importance due to its effect on yield and volumetric productivity (Bahrim et al., 2010; Portilla-Rivera et al., 2009). The cost for a microbial enzyme production represented almost $30 \%$ by fermentation medium (Portilla-Rivera et al., 2009). The medium commonly used for transglutaminase production from Streptomycesare not economically attractive. It contains expensive for medium components i.e. peptone, yeast extract, and many mineral salts.

Some studies that using cheaper medium by utilizing wastes from the agro-industry as carbon source have been carried out for the production of MTGase such as acid hydrolysates of sorghum straw (Tellez-Luis et al., 2004a), acid hydrolysates of wheat straw (Guerra-Rodríguez et al., 2012 ${ }^{\mathrm{b}}$ ), sugar cane molasses (Portilla-Rivera et al., 2009) and enzymatic or acid hydrolysates of potato (Guerra-Rodríguez \& Vazquez, 2013b; Guerra-Rodríguez et al.,2012a,b). Non-commercial potatoes that are considered as agricultural wastes can be used as medium for the microbial production of MTGase after being hydrolized with acid or enzyme. The acid hydrolysis of potato is aimed at obtaining the degradation products, such as furfural, 5-(hydroxymethyl)-2-furaldehyde and acetic acid that remain in the glucose solutions. These byproducts are known as inhibitors of microbial growth, which are lethal at the certain concentrations (GuerraRodríguez et al., 2012b; Wang et al., 2012; Zeni et al., 2011). Enzymatic hydrolysis of potato will generates glucose solutions that can be consumed by microorganisms without further treatments. In the enzymatic hydrolysis there are no microbial growth inhibitors exist (Delgado et al., 2009; Vazquez et al., 2009). However, the hydrolysis processes are time and enzyme consuming.
Guera-Rodríguez \& Vázquez (2013b) accomplished their previous research to eliminate the hydrolysis process. The potatoes were dried at $60^{\circ} \mathrm{C}$ before being ground. The potato powder dissolved in water along with skim milk and glycerol was used as the growth medium. Using the same strain, $S$. ladakanum NRRL 3191, the activity of transglutaminase obtained with this medium was increased by more than $300 \%$ compared with those obtained from hydrolysates of sorghum straw (TellezLuis et al., 2004a), sugar cane molasses with glycerol (Portilla-Rivera et al., 2009), with glycerol alone as carbon source (Tellez-Luis et al., 2004b) and with enzymatic hydrolysates of potato supplemented with yeast extract, corn steep liquor and casein (Rodríguez \& Vazquez, 2013a). The fermentation using dried potatoes, skim milk and glycerol was also faster (72 h) (Guera-Rodríguez \& Vázquez ,2013b) than those mentioned above (about 96h)(Tellez-Luis et al., 2004a; Portilla-Rivera et al., 2009; Tellez-Luis et al., 2004b; Rodríguez \& Vazquez, 2013a).

Kittikun et al. (2012) has prepared the alternative raw materials for fermentation medium with low cost using surimi waste water (SWW). This waste could have a negative impact on the environment but on the other hand it still contains high nutrients and minerals that can be used as medium component. The protein in SWW can be recovered and utilized to produce value-added product while environmental problems can be resolved. The protein hydrolisate from SWW can replace the expensive nutrients in culture medium such as peptone, tryptone, meat extract or yeast extract as a source of nitrogen (proteins, peptides, and amino acids) and organic phosphate (Afonso \& Borguez, 2002; Bourtoom et al., 2009). Kittikun et al. (2012) used fish protein hydrolisate (FPH) obtained from hydrolyzed SWW to produced MTGase from Enterobacter sp. C2361, Providencia sp. C1112 and S. mobaraensisas as control. The FPH was used to replace pepton in SPY medium (2.0\% soluble starch, $2.0 \%$ peptone, $0.2 \%$ yeast extract, $0.2 \% \mathrm{Mg}_{2} \mathrm{SO}_{4}$, $0.2 \% \mathrm{~K}_{2} \mathrm{HPO}_{4}$ and $0.2 \% \mathrm{KH}_{2} \mathrm{PO}_{4}$ ). The result showed that the strains entered the stationary phase longer $(42 \mathrm{~h})$ in SPY medium than FPH ( $36 \mathrm{~h}$ ) as well reaching maximum activity ( $48 \mathrm{~h}$ in SPY and $18 \mathrm{~h}$ in FPH).

\section{Application of MTGase on Fish Meat Processing}

MTGase can be applied to the raw material either in dry or rehydrated form depending especially on the properties of the raw material to which it is added. The temperature affects the reaction where higher temperatures require less time for the reaction between transglutaminase and free protein groups. Transglutaminase is active optimally in the range of 
temperature from 50 to $55^{\circ} \mathrm{C}$ (stable at the range of $0-60^{\circ} \mathrm{C}$ ) and $\mathrm{pH}$ from 6 to 7 (stable at pH 5-9). The enzyme can be inactivated easily by setting temperature at above $60^{\circ} \mathrm{C}$ with the duration of inactivation depends on the type of food stuffs (Vácha et al., 2006).

Restructuration of raw meats were previously carried out using $\mathrm{NaCl}$ and sodium tripolyphosphate, which resulted undesirable flavour changes as well as increasing sodium intake (Kuraishi et al., 2000; Muguruma et al., 2003). Many research works had been conducted to investigated the effects of MTGase on various meats, such as pork (Hong \&Chin, 2012; Pietrasik \& Li-chan, 2002), beef (Castro-Briones et al., 2009, Martínez et al., 2010, and Pietrasik, 2002), chicken (Abdulatef et al., 2009; Tseng, 2000; Sun, 2011), and fish (Uresti et al., 2006, Cardoso, 2007, Cardoso et al., 2010; Moreno et al., 2010). Some researchers had reported that the addition of exogenous MTGasecan improves drastically the textural characteristics (elasticity and firmness), the mechanical strength, and water-holding capacity of protein-based product, such as restructured steaks, sausages, hot dogs doner and other reconstructed fish and meat products (Kuraishi et al., 2000; Motoki \& Seguro, 1998; Ramirez et al., 2000). The treatment with MTGase would be expected to affect the ability of proteins to aggregate (Fernandez-Diaz et al., 2001; Herrero et al., 2008). Significant decrease in $\alpha$-helix content and increase in $\alpha$-sheets after addition of MTGase can be observed under microscope (Herrero et al., 2008).

In fisheries, transglutaminase is currently used to improve the mechanical properties of fish product (surimi, fillets, separate). Overall surimi products in the Southeast Asian region are estimated to be 315,800 metric tons in 2005 (Pangsorn et al., 2007). Surimi can be used to prepare a variety of processed foods such as kamaboko, kani (crab) kamaboko, chikuwa, satsuma-age, fish sausages, fish balls, etc. Highquality surimi yields flexible gel with white color. Although the quality of surimi products depends mainly on their gelling properties, but the product contained healthy and natural ingredient also possess added value for the consumer. The quality of fish mince or surimiand the types of ingredients used will affected

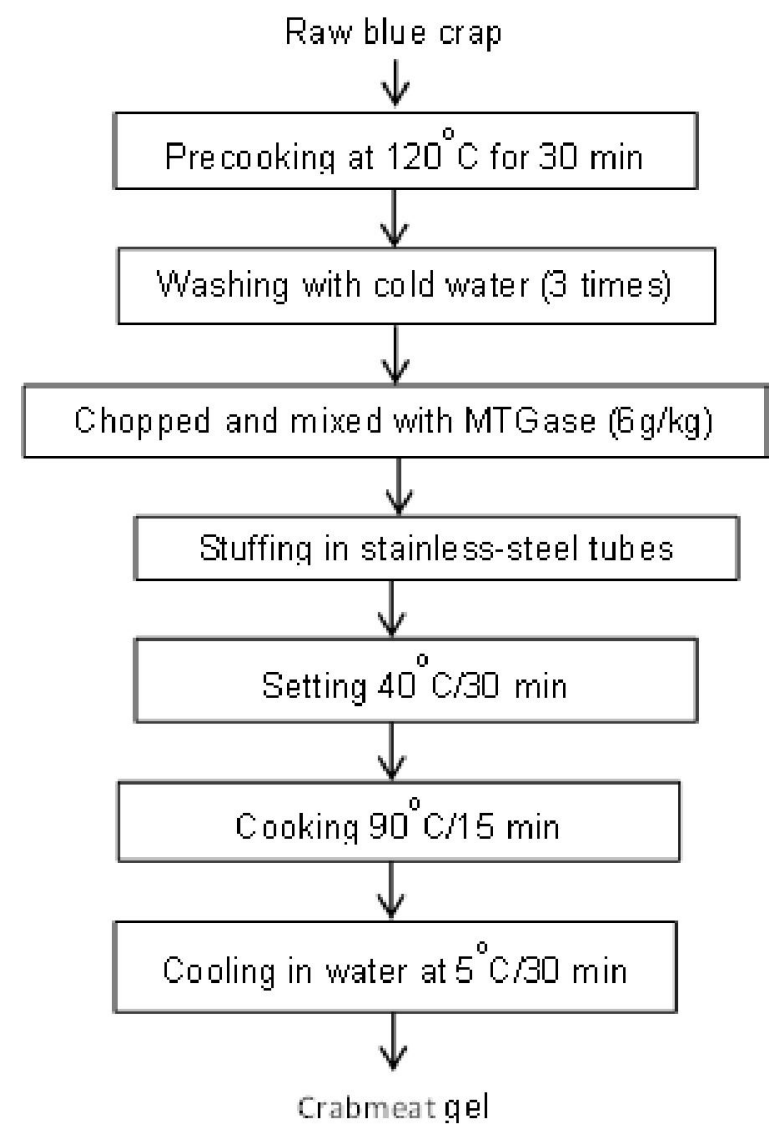

Figure 3. Flowchart of Crabmeat Gels Production (Martinez et al., 2014). 
the gel properties. Technological functions of the ingredients will determine textural properties. They also have antimicrobial and antioxidant and/or nutritional function.

MTGase has successfully been used in surimi to strengthen the gel, as reported by Martinez et al. (2014). Addition of MTGase and precooking treatment at $120^{\circ} \mathrm{C}$ for $30 \mathrm{~min}$ allowed interaction with MTGase and improve the mechanical properties of blue crab (Callinectes sapidus) gels. The flowchart of crabmeat gel process is presented in Figure 3. Benjakul et al. (2008) reported that the addition of MTGase from S. mobaraense in mince from lizard fish effectively increased the breaking force and deformation of gels. MTGase was also reported to increase the hardness and water holding capacity of common carp meat (Vácha et al., 2006).

Gel properties of threadfin bream (Nemipterus bleekeri) surimi added with fish gelatin in combination with MTGase were studied by Kaewudom et al. (2013). This study showed that addition of fish gelatin up to $10 \%$ in conjunction with 1.2 units MTGase/g surimi was recommended to obtain surimi with grade AA. Surimi gel network became finer and denser with the addition of $0.1 \%$ MTGase, as compared with the control gel (without MTGase).More compact and denser gel network was yielded by myofibrillar proteins which more effectively form the cross-linking in the presence of MTGase. Finer gel and structure which more ordered as a result of MTGase addition
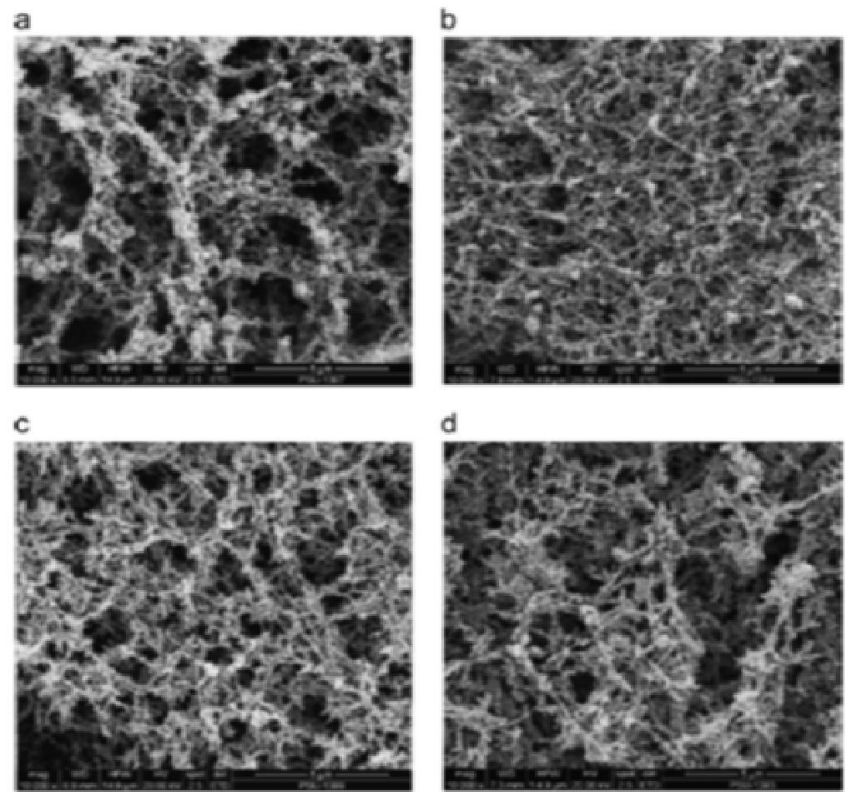

d
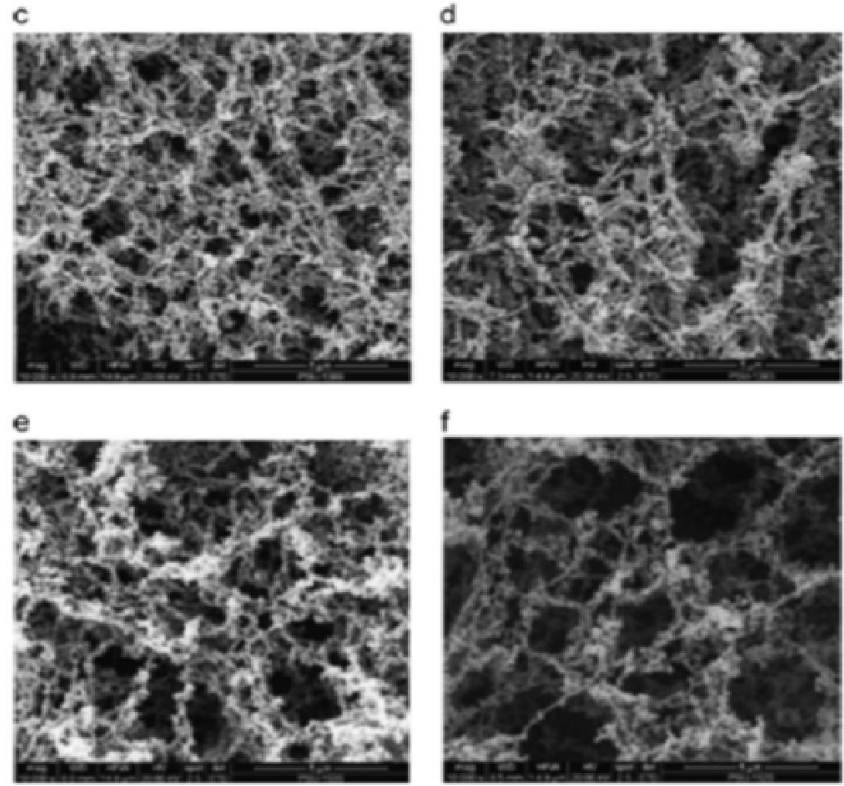

Figure.4. Electron microscopic images of surimi gel added with fish gelatin (FG) at different levels and MTGase at a level of 1.2 units g"1 surimi (magnification:10,000_): (a)surimi gel without gelatin and MTGase;(b)surimi gel added with MTGase 1.2 unitsg"1 surimi (without gelatin);(c)surimi gel added with $5 \%$ gelatin and MTGase 1.2 units g" 1 surimi;(d)surimi gel added with $10 \%$ gelatin and MTGase 1.2 units g" 1 surimi;(e)surimi gel added with15\% gelatin and MTGase1.2unitsg" 1 surimi; and (f) surimi gel added with 20\% gelatin and MTGase1.2 unitsg" 1 surimi Reprinted from : "Properties of surimi gel as influenced by fish gelatinand microbial transglutaminase" Kaewudom, P.,Benjakul, S. \& Kijroongrojana, K. 2013..Food Biosci.1 : $39-47$. 
correlated with higher breaking force and deformation as well as the lowered expressible moisture content. Microstructures of surimi gels added with fish gelatin at various levels in the presence of 1.2 units MTGaseg ${ }^{1}$ surimi are illustrated in Figure 3 (Kaewudom et al., 2013).

Chenarat \& Benjakul, (2013) reported the same result where in the presence of MTGase, indian mackerel fish protein isolates could undergo the crosslinking more effectively. Addition of MTGase yielded gel which was slightly more compact, with a denser gel network and smaller voids. Benjakul et al. (2008) also reported the agreement result that MTGase addition was able to improve the gel matrix of lizardfish surimi which became more compact and filamentous. Thus, alkaline solubilisation process and MTGase addition affected the gelling properties of Indian mackerel mince (Chenarat \& Benjakul, 2013)

Researchers at Research and Development Center for Marine and Fishery Product Processing and Biotechnology (RDCMFPPB) Jakarta have used MTGase produced by Streptoverticillium ladakanum to improve the properties of restructured meat made from Priacanthus macracanthus (Mata Goyang) and Euthynnusspp (Tongkol). The experiment results showed that gel strength of restructured fish made from Euthynnus spp. increasing up to 22 times compared to control (Fawzya et al., 2011a). The gel strength, springiness and cohesiveness of restructured fishmeat made from Priacanthus macracanthus increased with the addition of $1 \%$ MTGase along with $1 \% \mathrm{NaCl}$ and $1 \%$ sodium caseinat (Fawzya et al., 2011b).

\section{Prospect and Constraints for MTGase Development in Indonesia}

MTGase-based industry has promising prospects to be developed in Indonesia. The cheap raw material such as potatoes and cassava are abundantly available. In addition, the waste of fishery product processing can be utilized for enzyme production. Although many researches on screening of microorganisms, optimization of production and application of transglutaminase have been conducted and published, so far there is no report on transglutaminase-producing microorganisms of Indonesia origin, therefore the production and application of this enzyme still limited. So far the commercially available MTGase for food industry was produced only by Ajinomoto (TG-Activa). Therefore, research on transglutaminases, starting from screening of microbial producers towards the optimization of enzyme production and application, have intensively been done by us in Research and Development Center for Marine and Fishery Product Processing since 2009. Discovery of novel transglutaminases isolated from Indonesian microorganisms and further research and development towards cost-effective MTGase production will open great opportunities to develop domestic industry, particularly in fish processing.

\section{References}

Abdulatef, M.A., Nasu, T., \& Muguruma, M. (2009). Impact of transglutaminase on the textural, physicochemical, and structural properties of chicken skeletal, smooth, and cardiac muscles. Meat Science, 83, 759-767.

Afonso, M. D., \& Bórquez, R. (2002). Review of the treatment of seafood processing wastewaters and recovery of proteins therein by membrane separation processes-prospects of the ultrafiltration of wastewaters from the fish meal industry. Desalination, 142(1), 29-45.

Aluko, R. E. \& Yada, R. Y. (1999). Effect of a microbial calcium independent transglutaminase on functional properties of a partially purified cowpea (vigna unguiculata) globulin. Journal of the Science of Food and Agriculture, 79(2), 286-290.

Ando, H., Adachi, M., Umeda, K., Matsuura, A., Nonaka, A.M., \& Uchio, R. (1989). Purification and characteristics of a novel transglutaminase derived from microorganisms. Agricultural Biological Chemical, 53, 2613-2617.

Ashie, I. N., \& Lanier, T. C. (2000). Transglutaminases in seafood processing. Food Science and TechnologyNew York-Marcel Dekker-, 147-166.

Bahrim, G., lancu, C., Butu, N., \& Negoita, T. 2010. Production of a novel microbial transglutaminase using Streptomyces sp. polar strains. Rome Biotechnology Letter, 15, 5197-5203.

Bech, L., Halkier, T., Rasmussen, G., \& Schafer, T. (2000). U.S. Patent No. 6,100,053. Washington, DC: U.S. Patent and Trademark Office.

Bech, L., Norrevang I.A., Halkier T., Rasmussen G., Schafer T., \& Andersen J.T. (2001). Microbial transglutaminases, their production and use. US7179628.

Bech, L., Rasmussen G., Halkier T., Chiba O.M., Anderson N.L., Kauppinen M.S., Sandal T., inventor, Novozymes, assignee. (2002) Transglutaminase from oomycetes. US6428993.

Benjakul, S., Phatcharat, S., Tammatinna, A., Visessanguan, W. \& Kishimura, H. (2008). Improvement of gelling properties of lizardfish mince as influenced by microbial transglutaminase and fish freshness. Journal of Food Science, 73, 239-246.

Bourneow, C., Benjakul, S., Sumpavapol, P., \& HKittikun, A. (2012). Isolation and Cultivation of transglutaminase producing bacteria from seafood processing factories. Innovative Romanian Food Biotechnology, 10, 28-39. 
Bourtoom, T., Chinnan, M. S., Jantawat, P., \& Sanguandeekul, R. (2009). Recovery and characterization of proteins precipitated from surimi wash-water. LWT-Food Science and Technology, 42(2), 599-605.

Cardoso, C., Mendes, R. \& Nunes, M.L. (2007). Effect of transglutaminase and carrageen an on restructured fish products containing dietary fibres. International Journal of Food Science and. Technology, 42,12571264.

Cardoso, C., Mendes, R., Vaz-Pires, P., \& Nunes, M. L. (2010). Effect of salt and MTGase on the production of high quality gels from farmed sea bass.Journal of food engineering, 101(1), 98-105.

Castro-Briones, M., Calderón, G. N., Velazquez, G., Rubio, M. S., Vázquez, M., \& Ramírez, J. A. (2009). Mechanical and functional properties of beef products obtained using microbial transglutaminase with treatments of pre-heating followed by cold binding. Meat science, 83(2), 229-238.

Chanarat, S., \& Benjakul, S. (2013). Impact of microbial transglutaminase on gelling properties of Indian mackerel fish protein isolates. Food chemistry,136(2), 929-937.

Cui, L., Du, G., Zhang, D., Liu, H., \& Chen, J. (2007). Purification and characterization of transglutaminase from a newly isolated $<i>$ Streptomyces hygroscopicus $</$ i>. Food chemistry, 105(2), 612-618.

Dadabay, C. Y. \& Pike, L. J. (1989).Purification and characterization of a cytosolic transglutaminase from a cultured human tumour-cell line. Biochemistry Journal, 264, 679-685.

Date, M., Yokoyama, K., Umezawa, Y., Matsui, H. \& Kikuchi, Y. (2003). High level expression of Streptomyces mobaraensis transglutaminase in Corynebacterium glutamicum using a chimeric proregion from Streptomyces cinnamoneus transglutaminase. Journal of Biotechnology, 110, 219-226.

Delgado, R., Castro, A. J., \& Vazquez, M. (2009). A kinetic assessment of the enzymatic hydrolysis of potato (Solanumtuberosum). LWT Food Science and Technology. 42, 797-804.

Duran, R., Jungua, M., Schmitter, J. M., Gancet, C. \& Gaulas, P. (1998). Purification, characterisation, and gene cloning to transglutamianse from Streptoverticilliumc innamoneum CBS 683.68. Biochimie, 80, 313-319.

Fawzya, Y.N., Zilda, D.S., Poernomo, A., Indra, K, I. \& Nursyam, H. (2011a). Karakterisasi dan aplikasi enzim transglutaminase dari Streptoverticillium ladakanum pada daging lumat ikan mata goyang. Jurnal Pascapanen dan Bioteknol Kelautan dan Perikanan, 6, 2011, 157-166.

Fernandez-Diaz, M. D., Montero, P. \& Gomez-Guillen, M. C. (2001). Gel properties of collagens from skins of cod (Gadus morhua) and hake (Merluccius merluccius) and their modification by the coenhancers magnesium sulphate, glycerol and transglutaminase. Food Chemistry, 74,161-167.
Fernandez-Diaz, M. D., Montero, P. \& Gomez-Guillen, M. C. (2001). Gel properties of collagens from skins of cod (Gadus morhua) and hake (Merluccius merluccius) and their modification by the coenhancers magnesium sulphate, glycerol and transglutaminase. Food Chemistry, 74,161-167.

Griffin, M., Casadio, R., \& Bergamini, C.M. (2002). Transglutaminases: Nature's biological glues. Biochemistry. Journal, 368, 377-396.

Guerra-Rodríguez, E. \& Vazquez, M. (2013a). Microbial transglutaminase production on enzymatic hydrolyzates of potato (Solanum tuberosum) by Streptomyces mobaraensis. CYTAJ. Food. (in press) http://dx.doi.org/10.1080/19476337.2012.736414.

Guerra-Rodríguez, E., \& Vázquez, M. (2014). Evaluation of a novel low-cost culture medium containing exclusively milk, potato and glycerol for microbial transglutaminase production by Streptomyces mobaraensis. Chemical Engineering Research and Design, 92(4), 784-791.

Guerra-Rodríguez, E., Portilla-Rivera, O., Ramírez, J.A. \& Vázquez, M. (2012a). Modelling of the acid hydrolysis of potato (Solanumtuberosum) for fermentative purposes. Biomass Bioenergy, 42, 59-68.

Guerra-Rodríguez, E., Portilla-Rivera, O.M., JarquinEnriquez, L., Ramirez, J.A. \& Vazquez, M. (2012b). Acid hydrolysis of wheat straw: a kinetic study. Biomass Bioenergy, 36, 346-355.

Herrero, A. M., Cambero, M. I., Ordóñez, J. A., de la Hozand, L. \& Carmona, P. (2008). Raman spectroscopy study of the structural effect of microbial transglutaminase on meat systems and its relationship with textural characteristics. Food Chemistry, 109, 25-32.

Hong, G.P. \& Chin, K.B. (2010). Effects of microbial transglutaminase and sodium alginate on cold-set gelation of porcine myofibrillar protein with various salt levels. Food Hydrocolloids, 24, 444-451.

Iwata, K.I., Ishizaki, S.H., Handa, A.K. \& Tanaka, M.U. (2001). Preparation and characterization of edible films from fish water soluble proteins. Fish Science, 66, 372-378.

Kaewudom, P., Benjakul, S. \& Kijroongrojana, K. (2013). Properties of surimi gel as influenced by fish gelatin and microbial transglutaminase. Food Bioscience. 1: $39-47$

Kanaji, T., Ozaki, H., Takao, T., Kawajiri, H., Ide, H., Motoki, M. \& Shimonishi, Y. (1993). Primary structure of microbial transglutaminase from Streptoverticillium strain, Journal of. Biology and Chemistry, 268, 11565-11572.

Kikuchi, Y., Date, M., Yokoyama, K., Umezawa, Y., \& Matsui, H. (2003). Secretion of active-form Streptoverticillium mobaraense transglutaminase by Corynebacterium glutamicum: processing of the protransglutaminase by a cosecreted subtilisin-like protease from Streptomyces albogriseolus, Applied. Environment Microbiologyl, 69, 358-366.

Kittikun, A.H., Bourneow, C \& Benjakul, S. (2012). Hydrolysis of surimi wastewater for production of transglutaminase by Enterobacter sp. C2361 and 
Providencia sp. C1112 Food Chemistry. 135:11831191.

Kobayashi K., Hashiguchi K., Yokozeki K. \& Yamanaka S. 1998. Molecular cloning of the transglutaminase gene from Bacillus subtilis and its expression in Escherichia coli. Bioscience Biotechnology Biochemistry. 62:1109-1114.

Kumazawa, Y., Ohtsuka, T., Ninomiya, D. \& Seguro, K. 1997. Purification and calcium dependence of transglutaminase from sheep hair follicles, Bioscience Biotechnology Biochemistry. 61: 10861090.

Kuraishi, C., Nakagoshi, H., Tanno, H. \& Tanaka, H. (2000). Application of transglutaminase for food processing. Hydrocolloids. 2: 281- 285.

Lin,Y.S., Chao, M.L., Liu, C.H., Tseng, M. \& Chu, W.S. (2006). Cloning of the gene coding for transglutaminase from Streptomyces platensis and its expression in Streptomyces lividans. Process Biochemistry. 41: 519-512.

Liu, X.Q., Yang, X.Q., Xie, F.H., Song, L.Y., Zhang, G.Q. \& Qian, S.J. 2007. On-column refolding and purification of transglutaminase from Streptomyces fradiae expressed as inclusion bodies in Escherichia coli. Protein Expression and Purification. 51:179-186.

Martínez, B., Miranda, J.M., Franco, C.M., Cepeda, A. \& Vázquez, M. (2010). Evaluation of transglutaminase and caseinate for a novel formulation of beef patties enriched in healthier lipid and dietary fiber. $L W T$. Food Science and Technology. 1-8.

Martínez, M.A., Robledo, V, Velazquez, G., Ramírez, J.A. Vázquez, M. \& Uresti, R.M. (2014). Effect of precooking temperature and microbial transglutaminase on the gelling properties of blue crab (Callinectes sapidus) proteins. Food Hydrocolloids: 35: 264-269

Moreno, H.M., Carballo, J. \& Borderías, A.J. (2010). Use of microbial transglutaminase and sodium alginate in the preparation of restructured fish models using cold gelation: Effect of frozen storage. Innovative Food Science and Emerging Technologies. 11: 394-400.

Motoki, M. \& Seguro, K. 1998. Transglutaminase and its use for food processing. Trends Food Science and Technology. 9, 204-210

Muguruma, M., Tsuruoka, K., Katayama, K., Erwanto, Y., Kawahara, S. \& Yamauchi, K. (2003). Soybean and milk proteins modified by transglutaminase improves chicken sausage texture even at reduced levels of phosphate. Meat Science, 63:191-197.

Neilson, P. M. 1995. Reactions and potential industrial applications of transglutaminase. Review of literature and patents. Food Biotechnology. 9:119-156.

Noda, S., Miyazaki, T., Tanaka, T., Chiaki, O. \& Kondo, A. 2013. High-level production of mature active-form Streptomyces mobaraensis transglutaminase via pro-transglutaminase processing using Streptomyces lividans as a host. Biochemistry Engineering Journal. 74:76- 80.

Ogino, C., Kanemasu, M., Hayashi, Y., Kondo, A., Shimizu, N., Tokuyama, S., Tahara, Y., Kuroda, S., Tanizawa, K. and Fukuda, H. (2004). Over-expression system for secretory phospholipase D by Streptomyces lividans. Applied. Microbiology Biotechnology. 64: 823-828.

Pangsorn, S., Laong-manee, P. \& Siriraksophon, S. (2007). Status of surimi industry in the Southeast Asia. Training Department, Southeast Asian Fisheries Development Center, Thailand.

Pastermack, R., Dorsch, S., Otterbach, J.T., Robenek, I.R., Wolf, S. \& Fuchsbauer, H.L. 1998. Bacterial protransglutaminase from Streptoverticillium mobaraense: purification, characterisation, and sequence of the zymogen, European Journal of. Biochemistry. 257:570-576.

Patantis, G. Munifah, I., Chasanah, E. \& Saksono, B. (2009). Desain dan Skrining gen transglutaminase dari Streptomyces sp. Prosiding Temu Bisnis dan Seminar Nasional dalam Rangka 45 Tahun Riset Pasca Panen Perikanan.

Pietrasik, Z \& Li-Chan, E.C.Y. (2002). Binding and textural properties of beef gels as affected by protein, kappacarrageenan and microbial transglutaminase addition. Food Research International. 35: 91-98

Piredda, L., Farrace, M.G., Lo Bello, M., Malorni,W., Melino, G., Petruzzelli, R. \& Piacentini, M. (2003). Identification of "tissue" transglutaminase binding proteins in neural cells committed to apoptosis, FASEB J. 13:355-364

Portilla Rivera, O., Tellez Luis, S. \& Vazquez, M., (2009). Production of microbial transglutaminase on media made from sugar cane molasses and glycerol. Food Technology. Biotechnology. 47 :19-26.

Ramirez, J. A., Rodriguez-Sosa, R., Morales, O. G. \& Vazquez, M. (2000). Surimi gels from striped mullet (Mugil cephalus) employing microbial transglutaminase. Food Chemistry. 70:443-449.

Shi, Y.G., Qian. L., Zhang,N., Han. C.R., Liu, Y., Zhang, Y.F. \& Ma, Y.Q. (2011). Changes in morphology and activity of transglutaminase following cross-linking and immobilization on a polypropylene microporous membrane. Molecule .16:10046-10058.

Sommer, C., Volk, N. Pietzsch, M. (2011). Model based optimization of the fed-batch production of a highly active transglutaminase variant in Escherichia coli. Protein. Expression and Purification . 77: 9-19.

Sun, X.D. \& Arntfield, D. S. (2011). Gelation properties of chicken myofibrillar protein induced by transglutaminase cross linking. Journal of Food Engineering. 107: 226-233.

Tanaka, T., Kamiya, N. \& Nagamune, T. (2004). Peptidyl linkers for protein heterodimerization catalyzed by microbial transglutaminase, Bioconjug Chemistry. 15:491-497.

Tellez Luis, S.J., Gonzalez Cabriales, J.J., Ramirez, J.A. \& Vázquez,M. (2004a). Production of transglutaminase by Streptoverticillium ladakanum NRRL-3191 grown on media made from hydrolysates of sorghum straw. Food Technology and Biotechnology. 42:1-4.

Tellez-Luis, S.J., Ramirez, J.A. \& Vazquez, M. (2004b). Production of transglutaminase by Streptoverticillium 
ladakanum NRRL-3191 using glycerol as carbon source. Food Technology. Biotechnology, 42, 75-81.

Tseng, T.F., Liu, D.C. \& Chen, M.T. (2000). Evaluation of transglutaminase on the quality of low salt chicken meat balls. Meat Science, 55, 427-431.

Uresti, R.M., Velazquez, G., Vazquez, M., Ramirez, J.A. \& Torres, J.A. (2006). Effects of combining microbial transglutaminase and high pressure processing treatments on the mechanical properties of heatinduced gels prepared from arrow tooth flounder (Atheresthes stomias). Food Chemistry, 94, 202-209.

Vàcha, F., Novik1, I., Špièka, J. \& Podola1, M. (2006). Determination of the effect of microbial transglutaminase on technological properties of common carp (Cyprinus carpio L.) meat. Czech Journal of Animal Science, 51, 535-542.

Vazquez, M., Delgado, R., Jaime Castro, A. (2009). Modelling of the enzymatic hydrolysis of potato (Solanum tuberosum) using response surface methodology. Starch-Starke. 61, 601-609

Wang, Y., Yu, L. \& Wei, X. (2012). Monosaccharide composition and bioactivity of tea flower polysaccharides obtained by ethanol fractional precipitation and stepwise precipitation. Cyta Journal of Food, 10,1-4.

Washizu, K., Ando, K., Koikeda, S., Hirose, S., Matsuura, A., Takagi, H., Motoki, M. \& Takeuchi K. (1994), Molecular cloning of the gene for microbial transglutaminase from Streptoverticillium and its expression in Streptomyces lividans. Bioscience Biotechnology Biochemistry, 58, 82-87.

Yang, H.L., Pan, L. \& Lin, Y. (2009). Purification and on column activation of a recombinant histidine-tagged pro-transglutaminase after soluble expression in Escherichia coli. Bioscience. Biotechnology Biochemistry, 73, 2531-2534.

Yokoyama, K.I., Nakamura, N., Seguro, K. \& Kubota, K. (2000). Overproduction of microbial transglutaminase in Escherichia coli, in vitro refolding, and characterization of the refolded form. Bioscience. Biotechnology Biochemistry, 64,12631270.

Zeni, J., Colet, R., Cence, K., Tiggemann, L., Toniazzo, G., Cansian,R.L., Di Luccio, M., Oliveira, D. \& Valduga, E. (2011). Screening of microorganisms for production of carotenoids. Cyta Journal of Food, 9,160-166.

Zheng, M., Du, G., Guo, W., Chen, J. (2001). A temperatureshift strategy in batch microbial transglutaminase fermentation. Process in Biochemestry, 36, 525-530.

Zhu. Y. \& Tramper, J. (2008). Novel applications for microbial transglutaminase beyond food processing. Trends in Biotechnology. 26.

Zotzel, J., Keller, P. \& Fuchsbauer, H.-L. (2003). Transglutaminase from Streptomyces mobaraensis is activated by an endogenous metalloprotease. European Journal of Biochemistry, 270, 3214-3222. 